\title{
LIT Surveillance \& society ID Scanning, the Media and the Politics of Article Urban Surveillance in an Australian Regional City
}

\section{Darren Palmer}

School of Humanities and Social Sciences, Deakin University, Australia.

darren.palmer@deakin.edu.au
Ian Warren

School of Humanities and Social Sciences, Deakin University, Australia.

ian.warren@deakin.edu.au
Peter Miller

School of Psychology, Deakin

University, Australia.

peter.miller@deakin.edu.au

\begin{abstract}
Computerised ID scanning technologies have permeated many urban night-time economies in Australia, the United States, Canada and the United Kingdom. This paper documents how one media organisation's overt and tacit approval of ID scanners helped to normalise this form of surveillance as a precondition of entry into most licensed venues in the Australian city of Geelong. After outlining how processes of governance "from above" and "from below" interweave to generate distinct political and media demands for strategies to prevent localised crime problems, a chronological reconstruction of media reports over a three-and-a half year period demonstrates how ID scanning became the centrepiece of a holistic reform strategy to combat alcohol-related violence in this nightclub precinct. Several discursive techniques helped to normalise this "technological fix", while suppressing critical discussion of viable concerns over information privacy, data security and system networking. These included pairing reports of an initial "signal crime" with examples of "virtual victimhood" to stress the urgency of a radical surveillance-based response, which was supported by anecdotal statements from key "primary definers" highlighting the success of this initiative in targeting a wider population of antisocial "others". The implications of these reporting practices are discussed in light of the media's central role in reforming the Geelong night-time economy and broader trends in using novel surveillance technologies to combat urban crime problems at the expense of alternative measures that protect individual liberty.
\end{abstract}

\section{Introduction}

Since the late 1990s ID scanning has permeated many urban night-time economies in Australia, the United States (Cross 2005), Canada (Loukidelis 2009) and the United Kingdom (Hadfield, Lister and Traynor 2009). While the use of surveillance technologies to regulate alcohol supply is by no means new (Thompson and Genosko 2009), the constant battle to curtail the problems of alcohol-related violence and antisocial behaviour in and around licensed venues provides an apt setting for the use of various computerised surveillance technologies alongside an extensive "patchwork" of regulatory, behavioural and liquor-licensing controls (Hadfield, Lister and Traynor 2009; Palmer, Warren and Miller, 2011). However, despite the ideal of "perfect enforcement" (Mulligan 2008) offered by any "technological fix" (Bloomfield 2001), little direct evidence suggests these measures produce substantive improvements in patron behaviour or safer late-night entertainment precincts. As with open space closed circuit television (CCTV), the "doubtful impact" (Karstedt 2007: 149) of enhanced surveillance in delivering more than a vague promise of increased deterrence or rapid criminal detection (Armitage, Smyth and Pease 1999;

Palmer, Darren, Warren, lan, and Miller, Peter. 2012. ID Scanning, the Media and the Politics of Urban Surveillance in an Australian Regional City. Surveillance \& Society 9(3): 293-309.

http://www.surveillance-and-society.org | ISSN: 1477-7487

(C) The author(s), 2012 | Licensed to the Surveillance Studies Network under a Creative Commons

Attribution Non-Commercial No Derivatives license. 
Wilson and Sutton 2004; Lippert 2007; Manning 2008; Fussey 2008; Welsh and Farrington 2009), highlights the need to question political appeal favouring the adoption of novel crime prevention technologies.

The central role of the local print media in advocating the formal adoption and normalisation of ID scanners in the Geelong night-time economy mirrors the considerable literature documenting the open space CCTV "surveillance surge" (Murakami Wood 2009: 181) of the past two decades. This paper documents how the Geelong media used several well-recognised reporting techniques that magnified the scale of alcohol-related violence and the potential vulnerability of all nightclub patrons to support an initial ID scanners trial in early 2007 and its subsequent endorsement as the centrepiece of extensive reforms to the local night-time economy. Scant reference to any countervailing arguments associated with information privacy or alternative harm reduction methods helped to normalise this technology as a mandatory condition of entry into most of the city's late-night venues by June 2010. Even though the media's role as a central "from below" actor in this example is mediated by several local political trends (Stenson 2008), policy makers in other jurisdictions have expressly recognised that concerns over individual privacy, data security and information sharing remain marginal to the overriding desire to combat alcohol-related disorder (Law, Justice and Safety Committee 2010). Therefore, the favourable local depictions of ID scanners as a successful crime prevention measure in Geelong can fuel the broader appeal of this "technological fix" in regulating the urban night-time economies of many other Australian and international cities.

\section{ID Scanners, governmentality and the media's role in crime prevention debates}

Commonly used to control employee access into secured government buildings, private businesses (Kulinski and Monk 2008), or to prevent alcohol and tobacco sales to minors (Krevor et al 2003), ID scanners have now become a mandatory precondition of entry into most late-night venues in the Australian coastal city of Geelong (Palmer, Warren and Miller 2011). Located approximately 80 kilometres south-west of Melbourne, Victoria's largest regional city has a stable population of around 200,000 residents, a robust university culture and cosmopolitan aspirations that supplant its historical reliance on agriculture and light industry. After a brief pilot, ID scanners were formalised in November 2007 under a voluntary Liquor Accord developed between venue licensees, police and the local council. This technology replaces the manual inspection of a person's driver's licence, passport or other proof of age document upon entry into seven licensed venues in the Geelong Central Business District (CBD). ${ }^{1}$

A digital image of the identification document is scanned the first time a patron enters the venue, is stored in a fixed or portable computer located on-site, then automatically matched through computer software with a photograph taken of each patron on all subsequent visits. Stored records can be annotated to highlight whether an individual using the same document has been banned from any venue for an alcoholrelated offence. Data can also be networked across all participating venues or matched with related police records to offset the problems of manually recording incidents in venue logbooks or circulating photocopied lists of banned patrons with accompanying photographs to each venue.

While it is accepted the popular media help to "construct the very problems to which surveillance solutions are sought" (Barnard-Wills 2011: 548; Monahan 2010: 1), recent governmentality literature identifies a more complex interplay between the development of formalised crime prevention initiatives

\footnotetext{
1 When this research commenced ten venues participating in the voluntary Liquor Accord were involved in the initial ID scanners trial. Since the amended Accord was introduced in November 2007 this number has fluctuated mainly due to changes in venue ownership. Two businesses participating in the original trial have temporarily ceased trading. At the time of writing seven venues within the Geelong CBD and two located outside this declared area in the Greater Geelong region are using this technology. Several other venues in the neighbouring Surf Coast Shire have also introduced ID scanners after the initial Geelong pilot.
} 
"from above" and the diffuse processes of negotiation, implementation or resistance to these strategies "from below" (Lea and Stenson 2007; Stenson 2008). The media is a crucial non-state actor in this process, with the capacity to reinforce or challenge the "expert" voices of "primary definers" (Welch, Fenwick and Roberts 1997; McCahill and Norris 2002: 28) who shape contemporary crime prevention policies. This is a particularly striking feature of the politics behind the Geelong ID scanner initiative, which closely resembles the processes associated with the normalisation of CCTV as an "expected feature of public space" (Murakami Wood 2009: 186-187) in the contemporary urban landscape.

Lippert (2007: 33) demonstrates how "a wide array of actors and organizations not typically associated with governing" have considerable power to selectively develop "novel assemblages" of authoritative knowledge about crime prevention "from above", that are reworked to meet peculiarly localised political, urban development or commercial needs "from below". These processes of knowledge and policy transfer (Karstedt 2007; Coventry and Palmer 2008: 310) may or may not produce the desired short-, medium- or long-term objectives of revitalising urban precincts or improving public safety. However, although the real "cultural politics" of contemporary crime prevention often understates the media's role (Squires 2008; Stenson 2008; c.f. Hier et al 2007), the extensive literature documenting the expansion of open space CCTV systems persistently demonstrates how popular news discourses highlight the effectiveness of this technology in curtailing undesirable or serious criminal behaviour (Norris and Hobbs 1999: 60-88), often with little or no supporting empirical evidence.

Graphic headlines and in-depth news stories that stress the urgency for immediate preventative action help to legitimise computerised surveillance in "fighting crime", catching offenders or preventing terrorist plots. Media discourses advocating CCTV tend to focus on the "operational efficiency" of this technology "in an era of fiscal restraint" (Hier et al 2007: 738). However, these benefits simultaneously marginalise concerns over information privacy, civil liberties, function creep or alternative non-technological methods of combatting crime and antisocial behaviour. Such discourses are frequently accompanied by selective endorsements from key "primary definers" including senior police, politicians, local government officials, business managers and private security experts (McCahill and Norris 2002: 26-37; Barnard-Wills 2011: 550). However, Hier et al (2007) demonstrate the media can play an equally significant role in contesting such authoritative knowledge favouring the implementation or expansion of open space CCTV systems.

In Brockville, Ontario, selective media reporting both reflected and fuelled a groundswell of opposition "from below" to successfully challenge the voices of senior police and politicians advocating the installation of a public CCTV network. Persistent arguments highlighting the "potential utility [of CCTV] ... in addressing social issues including violence, vandalism and aggressive panhandling" (Hier et al 2007: 738), accompanied by considerable financial incentives to cover installation costs, were countered by proposals for expanded police numbers and a supporting "hybrid discourse, pitting small-town community privacy against big-city intrusive state surveillance" (Hier et al 2007: 739). This example shows the media can successfully help local communities resist empirical or political pressure "from above" that favours questionable or untested surveillance initiatives. Such resistance can be situated at various points on a binary plane and will be informed by any number of behind-the scenes alliances with policy makers or concerned citizens acting both within and outside the formal governance process.

Pressure "from below" opens up the capacity for new actors to enter the political process and challenge authoritative voices "from above" that extol the merits of new and untested crime prevention technologies. However, in a context where alcohol consumption is increasingly paired with various empirically documented individual and social harms, a predictable cause-and-effect binary is likely to favour any remedial "technological fix" or "surveillance surge". In practice, the story of regulating the night-time economy is far more complex. Identifying and responding to various forms of "criminogenic risk" (Innes 2004a: 17) requires unravelling a highly informal (Connelly 2011) yet sophisticated knowledge base involving complex nodal relationships between multiple public and private agencies (Hadfield 2008), the 
production of inaccurate or untimely data on the nature and extent of alcohol-related disorder (Newton and Hirschfield 2009) and limited evaluation of the variety of individual, spatial and supply-based policy interventions (Hadfield, Lister and Traynor 2009: 467-469; Palmer, Warren and Miller 2011). This highly contested knowledge-base opens the door to testing novel forms of security consumption (Goold, Loader and Thumala 2010), where many new surveillance technologies or data-sharing arrangements can be readily legitimised through incomplete or sensationalist evidence of risk or public insecurity. Further, despite Monahan's (2011: 497) well-informed claim that reflexive surveillance research must recognise new technology "also accelerates and augments the experiences of people considered to be of commercial value and low risk", media and political discourses produced within an emotive binary frame can readily manipulate these arguments to reinforce the urgent need for radical and relatively inexpensive automated surveillance techniques to protect individuals or whole communities (Thompson and Genosko 2009; Waiton 2010; Osmond 2010). The oppositional discursive frames characterising popular media and political debates can therefore reduce the complexity of alcohol-related crime to a simplistic, predictable for-and-against argument that is difficult for critics to challenge.

Barnard-Wills (2011) adopts Neuman, Just and Crigler's (1992) five-scale typology of dominant media frames to provide a model for analysing media depictions of surveillance practices. From a sample of 300 UK media articles dating back to 1990, the conventional for-and-against binary is reconfigured within five common frames comprising "economic themes, divisions of protagonists into "them" and "us", the human impact of issues, perceptions of control by powerful others, and the application of moral values" (BarnardWills 2011: 553). For example, the "them" and "us" frame favours increased surveillance by emphasising heightened public safety, security and crime reduction. By extension, opposing discourses question the desirability of mass surveillance techniques adopted by "security, the police, and the intelligence services" that also target innocent citizens, even if they are deployed to combat "hostile, external" threats from "criminals, terrorists, or those behaving in "antisocial" ways" (Barnard-Wills 2011: 556). This broader matrix of discursive variables enables detailed scrutiny of the interrelationship between multiple and competing rationales both for and against novel surveillance technologies in particular environmental contexts such as the night-time economy, alongside specific reporting practices that might endorse or challenge these proposals "from above" and "from below".

Innes' widely cited work on "signal" or "trigger crimes" (2004a; 2004b; 2007; Murakami Wood 2009: 181) is considered the central ingredient behind the adoption of new surveillance technologies to fight serious crime, innocuous "incivilities" (Girling, Loader and Sparks 1998) or perceived increases in extralegal self-help activities (Warren 2009). Hier et al (2007: 741) also suggest the absence of a signal crime might help explain the resistance to CCTV by the Brockville media. By extension, the pairing of "signal crime" with "virtual victimhood" (Peelo 2006) interrogates how stylised media narratives from crime victims or their relatives and friends can reinforce public fears. While such discourses often depersonalise the lived experience of actual crime victims, they simultaneously validate broader public concerns over the decline of social order represented by the threat of the "other" that is triggered by the initial "signal crime". When read alongside Barnard-Wills (2011), these micro-techniques of news production interweave with oppositional crime prevention debates at the more general level to help legitimise or resist calls for new surveillance measures to combat pressing crime problems. .

\section{Method}

This paper draws from a multi-faceted study into the introduction and normalisation of ID scanning as a precondition of entry into seven nightclubs in Geelong's 2.5 square kilometre CBD (Palmer, Warren and Miller, 2011). Between a "signal" crime first reported on 2 December 2006 and June 2010, Geelong's single daily print media outlet was pivotal in driving holistic reform to the region's previous Liquor Accord arrangements despite their favourable evaluation (Felson et al 1997; Rumbold et al 1998). The discussion below provides a chronological reconstruction of these events, informed by a critical discursive 
reading of a total sample of 298 articles examining alcohol-related violence in Geelong's daily newspaper during this three-and-a-half year period, and a detailed sub-sample of 23 news items documenting ID scanners as the region's key policy response.

Articles were traced by manually reading the daily Geelong newspapers then systematically crosssearching full-text records from over 100 Australian daily and weekly press sources in the Newsbank database. The Geelong sample was then compared to reports using the term "ID scanners" from all other Australian media sources between June 2005 and June 2010. Table 1 provides a numerical breakdown of key subject classifications for both the 23 Geelong ID scanner reports and the aggregate national sample of 168 articles. This comparison is striking for the overwhelming lack of critical media coverage of ID scanners in Geelong, even though this surveillance initiative became the centrepiece of extensive reforms to the night-time economy after the original "signal crime" in December 2006.

Of particular interest is how the chronological progression of discourses over this time frame reinforced the acceptance of ID scanners as the pivotal "technological fix" to combat violence and antisocial behaviour in the local night-time economy. This contrasts markedly with extensive public criticism over the management of Geelong's open space CCTV surveillance system after the initial "signal" event. Dominant framing and discursive techniques depicted in this sequence of reports illustrate how the Geelong media effectively silenced consideration of other prospective regulatory interventions that might viably target the "stubborn root causes" (Hadfield, Lister and Traynor 2009: 478) of alcohol-related harm. The impacts of these discourses on local policies and the subsequent normalisation of ID scanners in Geelong are then discussed in light of broader trends associated with the media's role in the political process surrounding the use and popular endorsement of new surveillance technologies to prevent crime.

\begin{tabular}{|c|c|c|}
\hline Issue & $\begin{array}{l}\text { Geelong } \\
\text { n. (\% of total) }\end{array}$ & $\begin{array}{ll}\text { Total } & \text { Australian } \\
\text { Articles } & \text { (including } \\
\text { Geelong) }\end{array}$ \\
\hline Scanners used to combat pub violence & $6(12 \%)$ & 50 \\
\hline Privacy implications & $1(2 \%)$ & 41 \\
\hline Scanners recommended by government and/or police & - & 22 \\
\hline $\begin{array}{l}\text { Scanners as part of a successful trial or violence- } \\
\text { reduction strategy }\end{array}$ & $8(57 \%)$ & 14 \\
\hline Scanner networking & - & 13 \\
\hline Biometric scanners & - & 7 \\
\hline Technological limits of ID scanners & - & 4 \\
\hline Calls for mandatory rollout of ID scanners & $1(33 \%)$ & 3 \\
\hline Cost & $1(33 \%)$ & 3 \\
\hline $\begin{array}{l}\text { Use of scanners for police investigations or } \\
\text { enforcement of bans }\end{array}$ & $5(71 \%)$ & 7 \\
\hline Public perception & $1(50 \%)$ & 2 \\
\hline ID scanners in take-away outlets or bottle shops & - & 2 \\
\hline Total & $23(13.6 \%)$ & 168 \\
\hline
\end{tabular}

Table 1: Australian and Geelong Media Reports on ID Scanners, June 2005-June 2010 


\section{The Geelong rape as a signal crime}

On Saturday 2 December 2006, the first reports of a "BRUTAL CITY RAPE" allegedly committed by two "ANIMALS" in the early hours of 1 December (Unknown Author 2006a: 1), contrasted the "grisly" description of brutal violence in a dingy public alcove against daytime family Christmas celebrations in the Geelong CBD. As "children and parents lined Malop St to watch the annual Gala Day parade" (Unknown Author 2006a: 1), they were quizzed on their impressions of an attack they, or many police in the area, were unlikely to have known about. "Its not a nice place to live anymore, it's getting more and more dangerous" cited one attendee, while another mourned the good old days when "we could walk home at two or three in the morning" safely (McNamara 2006a: 4). These statements from ordinary people illustrate how a single event can generate immediate anxieties about the risks of criminal violence amongst people who do not routinely participate in the night-time economy.

It took little time for the local media to adopt a uniquely self-appointed investigatory and policy-building function targeting the seemingly ever-rising problem of alcohol-related violence in and around the nightclub precinct. The press used several tools to heighten perceptions of risk amongst daytime CBD users, including detailed reports on the progress of each element of the investigation and publication of an enlarged map of the nightclub precinct to reinforce its character as tainted space (Breen 2006a; McNamara and Breen 2006: 5). Although the local council had implemented an open space CCTV system in the CBD at considerable expense to ratepayers, it was only monitored in real-time during peak periods on Friday and Saturday nights. This management glitch sparked immediate criticism of the council's management of the CCTV system, which forced police to trace the movements of two suspects by sifting through hours of footage from several publicly operated cameras dotted throughout the CBD and a private camera located directly above the alcove where the incident took place. The audacity of this crime and the council's stance on CCTV monitoring was reinforced by publication of a photograph depicting one of several fixed signs clearly warning people that the CBD is a "camera surveillance area" (Tucker 2006a: 5).

In the ensuing days front-page banner headlines such as "RAPE HORROR: Help Catch the Cowards" (Unknown Author 2006b: 1) demonstrate the level of outrage associated with this signal event. This was only moderated by a more measured plea from police in a page-3 feature article titled "Help Them Catch These Monsters. Police Renew Calls for Rape Witnesses" (Bennett 2006a: 3). Persistent references to "monsters" galvanized public fears that the two unknown suspects could strike again. This soon transformed into expressions of anger vented in text messages from several readers that were reprinted alongside reports documenting the progress of the investigation, which suggested "( $t$ )he rapists should get death by fireing (sic) squad, u godamn animals" and warned:

"... the scum that viciously raped that poor girl fri morning. U will be caught. Turn yourselves in. Karma will get you losers" (Bennett 2006a: 3).

These signals of outrage contrast with the circumspect narrative of a rape victim who was "attacked in the heart of Geelong after going clubbing with a group of friends" several years earlier (Whalley 2006: 4). By juxtaposing this example of "virtual victimhood (Peelo 2006) against the outrage over the signal crime, the local press presented the 1 December rape as the logical end-point to a more systemic problem of alcohol-related violence in a night-time entertainment industry hitherto derelict in its "moral and civic duty to educate the public to the dangers lurking inside bottles and cans" (Editorial 2006: 17). 


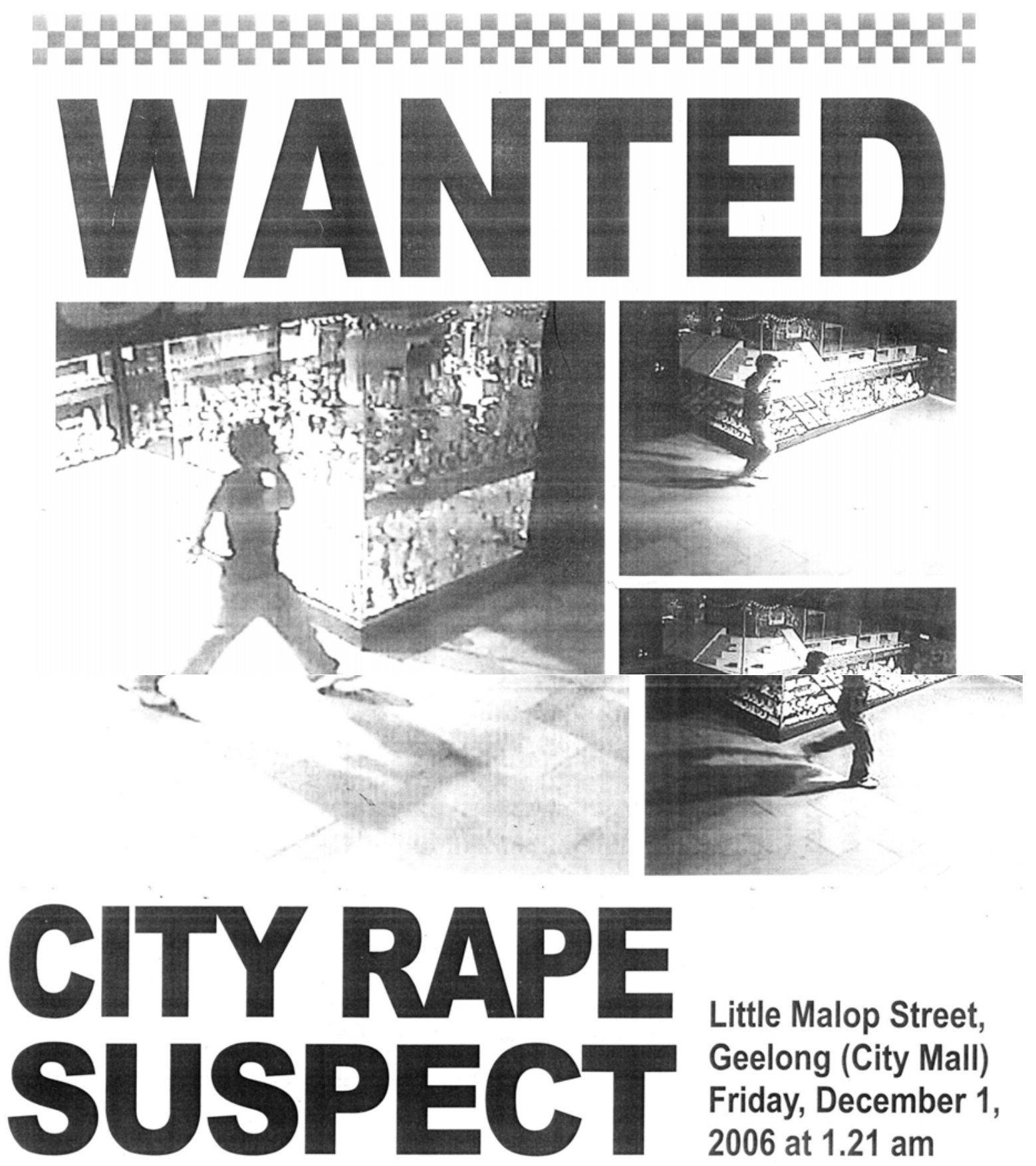

\section{Call Crime Stoppers 1800333000}

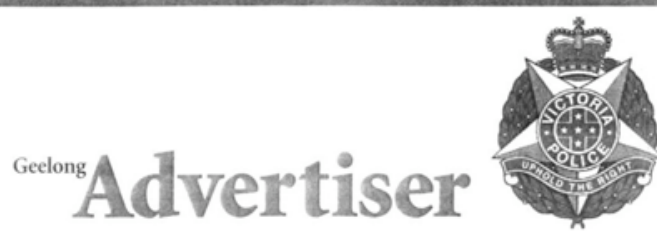

Figure 1: Wanted Poster (Geelong Advertiser 7 December: 24-5) 
Perhaps the most controversial step in the "hunt for (the) suspect" (McNamara 2006b: 4) involved the publication of a double page Crime Stoppers Wanted Poster containing several CCTV images from a camera located near the crime scene. The poster was part of a campaign encouraging members of the public to offer police any "tips" (Lippert and Wilkinson 2010) that might assist with identifying the man depicted in the poster, or a second muscular man hidden from the camera's gaze (Tucker 2006b: 1) who was later eliminated from the investigation. Citizens could lodge their "tips" through the official Crime Stoppers telephone hotline or by reporting to a police "information caravan" established in the CBD. The editorial accompanying the Crime Stoppers poster, which was endorsed by the head of the Sexual Crimes Unit, urged readers to "saturate the city with images of one of the chief suspects" and pressure either of these two "cowards" to "hand themselves in" (McNamara 2006b: 4).

"We want this poster stuck in every shop window and staff room and on every lamp post and out-house in the city.

By tonight we hope that each stride this man takes and every time he turns his head, he will be confronted by his picture...

We want his relatives, his friends, workmates, neighbors and enemies to see the poster and do the right thing and contact the police" (McNamara 2006b: 4).

Wanted posters (Oliver 1999) and Crime Stoppers advertisements magnify discriminatory racial typecasting within the criminal justice system by creating a perception that "visible minorities" are disproportionately involved in newsworthy street crimes or robberies (Lippert and Wilkinson 2010: 146147). Although the Geelong Crime Stoppers images contained no discernible racial element, the strategic use of grainy CCTV footage generated its own problematic feedback loop. The community invariably feared repeat acts of violence while these unidentified "monster(s)" remained at large, yet police could only obtain a positive identification of the suspect(s) by relying on accurate "tips" from the community. Ironically, violent crimes are rarely "solved" through such reactive uses of CCTV systems that are ultimately deployed to prevent crime (Lippert and Wilkinson 2010: 143-144). Nevertheless, the Geelong Crime Stoppers poster was prominently displayed in shop windows and on lampposts throughout the city in the ensuing days (McNamara 2006c: 3). As locals remained critical of the lack of television coverage of the incident and its investigation, one Melbourne television network "better known for broadcasting crime shows than for catching criminals" offered to digitally enhance the images to positively identify the key suspect. A reference to the resourcing implications of the investigation implies this technical expertise incurred some additional financial costs (Tucker 2006d: 7). Meanwhile, local news coverage continued to make periodic references to the impact of alcohol-related violence on victims, with a page 3 "EXCLUSIVE" letter from the victim's mother (Tucker 2006c: 3) and accompanying interview outlining how family and friends were content to "take each day as it comes" but had seriously contemplated moving elsewhere (Tucker 2006e: 4-5).

Pressure to develop concrete reforms to the region's night-time economy was magnified by the forthcoming annual summer tourist influx, with the CBD's nightclubs extremely popular amongst young holidaymakers. Two further "horrific" gang-bashings involving young male victims became expressly linked to the "brutal rape in Lt Malop St" (Pike and Breen 2006: 4). Senior police were called in as "primary definers" to allay the community's growing outrage. The region's police Inspector offered reassurances of a more visible police presence during the 2006-07 summer holiday season, despite citing data indicating aggregate assault rates had declined in the lead-up to the rape (Smith 2006: 3). The Chief Commissioner of the Victoria Police also entered the debate by highlighting the merits of the existing Liquor Accord structure and its collaborative problem-oriented focus (Bennett 2006b: 5). These statements clearly sought to dampen public demands for a rapid solution to a problem that seemed to be spiraling out of control with each new report of violence. However, the local media's preoccupation with 
the progress of the rape investigation also diverted attention away from any positive impacts of the Accord, which reinforced a broader perception that not enough was being done to combat alcohol-related violence in the $\mathrm{CBD}$.

A further marker of community frustration involved the link between responsible parental surveillance and increased safety in the nightclub precinct. The most prominent community-based response involved offers from several concerned parents to voluntarily monitor the CCTV cameras in non-peak periods from Sunday night through to Friday mornings. After reports documenting one mother's suggestion to "give up a couple of evenings a week" to monitor the cameras given the impracticality of having "police officers stationed on every corner" (McNamara 2006d: 3), several other parents joined this chorus. This was as much an attack on the local council's failure to "re-evaluate their (economic) priorities" and appoint professional CCTV monitors, as an expression of the desire for some parents to extend their own gaze into the night-time economy to allay any fears about the activities of their own children. The following quotes demonstrate the community's bewilderment over the local council's inaction regarding CCTV monitoring that also reinforced the mainstream public's faith in a CCTV surveillance system, which, if duly monitored by volunteers, would provide a sufficient disincentive for wrongdoers to continue their violent behaviour.

"I heard they want to put a ferris wheel up. Well wouldn't that be lovely? We can sit on the ferris wheel while our children get assaulted ...

I think really there's dozens of young retirees in this town that would get behind it [the manning of CCTV cameras by volunteers]' ...

... The council has spent so much on beautifying the city but yet an incident like this will keep people away. It's unfortunate that protection is needed but that's reality ...

... The group said they couldn't understand why surveillance cameras weren't manned on a Thursday night when it was common knowledge it was a busy night for university students to go out and party" (McNamara 2006e: 4).

The local Chief Inspector was "happy to welcome ... (any volunteers) into the police station where the monitoring is carried out". However, this would require various levels of official endorsement given the local council managed the CCTV infrastructure, while all monitoring took place within the police station. Despite these formalities, community spokespeople were "confident enough volunteers would step up" to distribute the load equitably so "everyone would only have to do a few shifts a year" (McNamara 2006e: 4). This development points to the possibility that any proposed reforms to the night-time economy would involve some form of surveillance creep.

As the unknown offender remained at large in the build-up to the 2006 Christmas holiday period, each report detailing the progress of the investigation reiterated the general pattern of media and community outrage at the initial signal crime and any other incidents contributing to the malaise of violence and insecurity in the night-time economy (Prytz 2006: 14-15). Editorials stressed how news of the 1 December rape "re-traumatized" many survivors of sexual assault, who were forced "to confront their nightmares yet again" (Moore 2006: 17) either alone or with the assistance of professional caseworkers. These discourses reminded readers of the importance of this crime as a signifier of community disgust that made all legitimate clubbers physically vulnerable. Possible reforms were therefore justifiably extreme and favored preserving the rights of victims over the "legal rights of criminals", who unfairly benefitted from lenient sentencing and early release policies. Only mandatory sentencing for violent crimes would end the "revolving door policy for criminals" and dissipate community "anger as ordinary people become sick and 
tired of the seemingly condescending attitude of a group of unelected people [judges] appointed by politicians" (McLure 2006: 37).

Throughout, the voices of those routinely participating in the night-time economy were silenced by the three-way focus on the "monster(s)" who perpetrated the violent rape, the local council that aided and abetted through its inadequate CCTV monitoring policies, and the broader processes of justice administration represented by a politically self-serving legislature and an out-of-touch judiciary. Police were notably immune from criticism given the extraordinary resources dedicated to "hunting down the offender" (Tucker 2006f: 4). The Sexual Crimes Unit provided "seven officers" as opposed to the usual "four or five detectives" appointed in the first few days of a rape investigation, while "other police units" contributed various unspecified forms of assistance. These clear reassurances that police were doing their best in trying circumstances sought to convince the community it was only "a matter of when he [the offender] is caught, not if".

Geelong could finally rest easily on Christmas Day with reports that six specialist officers apprehended Luke Gill after a late-night raid at his family home on Saturday 23 December (Unknown Author 2006c: 1). His application for bail at an out-of-court hearing was rejected, ensuring this monster would fittingly spend "Christmas in a police cell" (Tucker, 2006g: 2). Police also informed the victim's family of the arrest during the early hours of Sunday morning (Tucker 2006h: 2), enabling the community to focus on organizing several post-Christmas fundraising efforts "to help show the young victim that Geelong people cared" (Tucker 2007: 5).

Since 2006, the local media's periodic references to this signal event have reinforced the need for ongoing vigilance in managing alcohol-related violence in the Geelong CBD, particularly when other examples of violence in and around the nightclub precinct become newsworthy (McNamara 2007: 3). While reports of Luke Gill's trial were confined to the court reporting section of the newspaper, the perceived lenience of his 19-year imprisonment term reignited public "outrage" (Craven 2010: 7). This is despite Gill's initial aggregate sentence being one month lower than the average for murder in Victoria (Sentencing Advisory Council 2007: 16) and express judicial recognition that although he was a "multi-drug user" with "a longterm alcohol problem", neither drugs nor alcohol were "in any way responsible for you committing [these intentional] crimes" (R.v. Gill 2010: para 29). However, the main legacies of this signal crime relate to its symbolism in undermining this community's feelings of safety (Palmer, Warren and Miller 2011), through press discourses emphasising the widespread feelings of insecurity and the prospective randomness of criminal victimization within the Geelong nightclub district. These discourses can only be reconciled by the equally proactive endorsement of the ID scanning pilot as the key response to this pervasive decline of social order, which later became formally entrenched in a systematically revised Liquor Accord.

\section{The formal response}

It is difficult to gauge the extent of behavioural change amongst nightclub patrons after the Geelong rape. However, the centrepiece of the revised Liquor Accord launched 11 months after the initial signal crime involved the formal introduction of ID scanners as a mandatory form of surveillance to regulate entry into all "high-risk" venues licensed to trade after $1.00 \mathrm{am}$. As Table 1 indicates, the Geelong press has devoted comparatively little critical attention to this initiative since it was first raised by the local Nightlife Association. Prevailing discourses within this overwhelmingly small sample of reports also clearly demonstrate a resistance to documenting any major problems or citizen concerns associated with the initial ID scanners trial or its subsequent normalisation in the Geelong nightclub precinct.

The only reported criticisms of ID scanners in this 3.5 year sample involved statements from two people interviewed in a vox pop piece on 19 January 2007 when the proposal was first mentioned in the local press (Breen 2007a: 7). One expressed "disgust" at the prospect of not knowing "who's got your details 
and where they could end up", while the other suggested "they obviously need more police and bouncers" to resolve the problems of violence in the local night-time economy. These sole dissenting voices are buried within subsequent depictions of the ID scanners trial and rollout as an unqualified success in reforming the Geelong night-time economy. This contrasts with the comparatively robust discussion of the privacy implications of ID scanning in most other Australian print news sources since 2005.

From its inception in May 2007, the ID scanner trial was depicted as a "success" either in its own right (Gladman 2007: 7) or in conjunction with various other initiatives to combat violence in and around the CBD nightclub precinct. Some measures, such as a mandatory 2.00 am lockout from all late-night venues, were never formally pursued (Whalley 2008b: 4). Notably, initial discourses of "success" support Monahan's (2011) call to examine the utility of new surveillance technologies. ID scanners were praised because they caused few delays in long queues as personal identity documents were scanned and patrons were photographed. This benefit was supplemented with anecdotal quotes from security personnel indicating that patrons had "no objections" to this technology, which had produced an immediate reduction in violence as the usual "handful of people who threatened to cause trouble decided to leave ... because their details had been recorded" (Gladman 2007: 7). As the trial progressed, reports police had successfully used scanned information to apprehend "a nightclub attacker ... within minutes of an alleged attack" inside one CBD venue (Smith 2007: 3), signify the capacity of scanners to assist in rapidly detecting violent patrons, particularly where CCTV camera footage is unavailable. In this case, it only "took two minutes on a scanner" to obtain a positive identification of the suspect after the victim inspected several photographs stored within this club's computer system before being "carted off in the ambulance" for treatment. "Within 16 minutes the guy was caught". This compelling preliminary endorsement is a signal event in its own right, providing the basis for the local press to deem the ID scanners trial a success due to its efficiency in helping to "identify and weed out trouble makers" (Breen 2007b: 3; 2007c: 4). This clear benefit supersedes the financial costs of between " $\$ 8000$ and $\$ 13000$ " for installing the technology and any allied delays with its formal adoption pending systematic revision of the Accord.

Proposed amendments to the Accord targeted two key regulatory sites (Palmer, Warren and Miller 2011). The first involved agreed principles of managing liquor supply within the CBD under various schemes endorsed by the Victorian state government. When repackaged in Geelong they were acclaimed as a benchmark "defensive measure" for minimising violence in and around late-night venues (Editorial 2009: 21). Measures included replacing glass receptacles with plastic, a renewed commitment to responsible alcohol service requirements under state liquor-licensing laws and the adoption of a revised accreditation scheme for venue staff. The second involved several initiatives to improve surveillance within the nighttime economy, including agreed minimum standards for enhanced CCTV recording capacity in and around all CBD venues, the introduction of a two-way radio system enabling security staff to report violent incidents directly to police, the circulation of banned patron lists amongst police and all venue operators and the introduction of computerised ID scanning systems as a mandatory condition of entry into any "high risk" venue party to the Accord. Interestingly, after several meetings throughout 2007 attended by a core of eleven volunteers, the proposal to monitor the council's CCTV network was ultimately abandoned once it became clear the formal requirements of successfully obtaining a police clearance, completing a selection interview, undertaking accredited training and working late at night, on weekends and public holidays would be too onerous.

While the Geelong press applauded the new Accord as a marker of the community's willingness to "take ownership" of the problem of alcohol-related violence (Editorial 2009: 21), any judgments regarding the effectiveness of ID scanners must be qualified by questions surrounding the maintenance, security and officially sanctioned uses of scanned data (Palmer, Warren and Miller 2011; Law, Justice and Safety Committee 2010: 24-27). The complex legal and technical issues associated with using surveillance to prevent crime have the potential to counteract their perceived effectiveness in reducing harm (Manning 2008). Anecdotal reports suggest there has been "a reduction in serious assaults and antisocial behaviour" 
and "fewer battered and bleeding people in the queues at the accident and emergency department of Geelong Hospital" since the introduction of the revised Accord (Editorial 2009: 21). However, empirical support for any reductions in violence directly attributable to ID scanners remains absent.

The proximity between the launch of the revised Accord and the twelve-month anniversary of the Geelong rape led to a feature article reflecting on how the ID scanner trial helped to "clean up Geelong's streets" (McNamara 2007: 3). The press depicted ID scanners as the cornerstone of a "range of security measures targeting violence" that were ultimately subject to ongoing political contest between the local council and the state government, culminating in "a community safety petition signed by more than 33,000 people calling for more police in the city's CBD". However, "anecdotal evidence from the city's leaders" pointed to a marked reduction in the number of "serious bashings" since the ID scanner pilot, with a "host of initiatives" including "increased police foot patrols", improved "radio communication between police, nightclubs, the safe city taxi rank and late-night food venues" and more systematic "camera surveillance" also part of the renewed "partnership approach". Invariable political tensions would ensure the impracticality of the community's preference for "saturating the streets with police and having 24-hour, seven-day a week camera surveillance". Nevertheless, after the revised Accord was launched, the local press focused almost exclusively on the benefits of ID scanners in assisting police and venue operators to enforce a new state liquor-licensing banning notice scheme implemented "from above" (Oates 2008: 3). This development represents a crucial intersection between formal legislative reforms "from above" and the localised regulatory practices operating in the Geelong CBD.

Amendments to the Liquor Control Reform Act (1998: Part 8A, Division 1) enable police to immediately ban any person from a "declared area" for up to 24-hours if they have engaged in a range of listed offences. A breach of this order leads to immediate removal of the person from the area, and a possible criminal conviction with heavy fines if the order is breached. This scheme is also a formal punishment for a range of violent, sexual and alcohol-related offences occurring within a designated area that carry a maximum imprisonment term of less than twelve-months. Police retain the discretion to impose an on-thespot 24-hour order, which may be formally extended for no more than 12-months if the Director of Public Prosecutions or any member of the Victoria Police convinces a court that an additional ban "may be an effective and reasonable means" of preventing an offender from committing further offences within the declared zone. These reforms currently apply to thirteen ${ }^{2}$ regions in Victoria, with four located in the Melbourne metropolitan area and several in regional areas including the Geelong CBD (Adam 2008: 5). Given ID scanners were already required under the revised Accord, it was merely a question of networking the systems operating at each venue to streamline the enforcement of this new legislative regime. With both the technical infrastructure and a clear policy in place, Geelong could now efficiently implement "24-hour bans across all venues" and provide an enforcement model for all other designated zones to follow. Police could also be issued with scanners to streamline the processing of venue bans "electronically from the station" (Whalley 2008a: 5).

Once these reforms were enacted, a security expert charged with managing the Geelong ID scanning system became the key "primary definer", who applauded the community's leadership in using this technology. Unlike its ad hoc adoption in other designated zones, Geelong's innovative approach enhanced communication between CBD venues and police to provide the benchmark for enforcing the banning notice regime.

"If I went out on Saturday night in central Melbourne and they took my details they wouldn't have the same technology to enforce it as we have here in Geelong" (Whalley 2008a: 5).

\footnotetext{
2 At the time this research was conducted and under the original legislative amendments, ten locations including the Geelong CBD were formally listed as "declared areas".
} 
The success of ID scanners has subsequently been framed in light of the failure of some Geelong venues to introduce the technology. This is considered to undermine the flow of information about banned persons seeking to enter the region's "high-risk" venues (Oates 2008: 3). For example, after a "19-yearold student" was "king-hit" inside one venue that had dispensed with its system after a change of proprietorship, reports focused how mandating their deployment "could have quickly led to the arrest" of this perpetrator. The report stressed how this incident forced the club's new manager to "urgently" consider reintroducing this technology (Dorman 2008: 3).

Many reports also emphasised the strong deterrence value of ID scanners, which have the potential to detect more "students or people aged between 18 and 25" for "riotous or offensive behaviour or liquorlicensing law breaches", including "refusing to leave premises, underage drinking, urinating in public and using threatening words" (Tucker 2009b: 7). This enables police to widen the net of surveillance over the night-time economy by efficiently issuing short-term bans and more fines to a larger population of young clubbers. Pending the networking of the Geelong scanning system, one report in May 2009 detailed the role of ID scanners in enforcing the first extended ban imposed by the local magistrate's court against a 19 year-old "repeat offender" (Devic 2009a: 3). News of how the "mug shot" of "Publican enemy no. 1" had been "emailed to publicans" and "stored on a database ... linked to ID scanners" accompanied prominent statements outlining maximum fines of up to $\$ 2,200$ for breaching a police-issued banning notice under the new Victorian laws (Devic 2009a: 3). This incident reinforced the "deterrent" value of ID scanners in combating antisocial behaviour (Dorman 2008: 3). Subsequent reports of successful enforcement actions using this technology, in absence of any major critique of its problematic legacies, ignite strong calls to mandate its adoption in all late-night venues in Geelong and surrounding regions under periodic revisions to the Accord (Tucker 2009a: 9) or to extend their use in other locations, such as "the safe city taxi rank" (McNamara 2007: 3).

Geelong's leadership is clearly prized by the local media. Many “(c)apital cities throughout Australia and New Zealand" including Brisbane, Newcastle, Auckland, the Melbourne bayside suburb of Frankston (Breen 2008: 7) are considering the Geelong model as the basis for reforms to their own night-time economies. ID scanners offer a welcome contrast to more overtly punitive methods of combating alcoholrelated disorder, such as the introduction of "New York-style vigilantes to take a zero-tolerance approach to crime on the Gold Coast's nightclub strip". Individual venues in neighbouring rural towns have also followed Geelong's lead by implementing their own systems, which hints at the possible networking of scanned data throughout regional Victoria (Paton 2008: C01; Tickell 2008: 9). However, support for this technology is by no means uniform, with some venues cautious about its privacy implications (Devic 2008: 4). Nevertheless, it is clear the dominant media focus on the successes of the ID scanner trial has helped normalise this technology in the Geelong night-time economy at the expense of any deeper consideration of alternative methods to augment the current range of late-night recreational options, such as "trading from coffee and food carts", "roving street entertainment", the construction of "outdoor entertainment areas" or permanent "stages to broadcast major events" and improved public transport (Tucker 2009a: 9).

Notably, since the pilot and rollout of ID scanners, there has been a marked shift in the local media's depiction of the major sources of fear, disorder and insecurity within the Geelong night-time economy. The predatory "monsters" who generated so much community outrage after initial signal crime no longer appear to be of concern. The routine targets of increased surveillance now encompass a more nebulous population of "troublemakers" (Gladman 2007: 7; Breen 2007b: 3; Breen 2007c: 4; Adam 2008: 5; Oates 2008: 3; Tucker 2009b: 7), “drunks" (Tucker 2009b: 7), "thugs" (Breen 2008: 7; Dickens 2009: 3; Devic 2009b: 28), "drunken thugs" and "hooligans" (Devic 2009a: 3), "aggressive grog-fuelled yobbos" (Whalley 2008a: 5), "idiots" (Breen 2008: 7) and "underage drinkers" (Gladman 2007: 7). In keeping with the region's "tough approach" to combating the "alcohol scourge" (Whalley 2008a: 5), persistent acts of "booze-fuelled violence" (Craven 2009: 1; Dickens 2009: 3) and "thuggery" (Devic 2009b: 28), ID 
scanners now represent a form of high-tech "public policy as pest control" aimed at "shooing away vermin" through a familiar discursive frame aimed at deterring low-level antisocial misconduct (Squires 2008: 304). Computerised surveillance is now embedded within the revised Accord to "hammer home the message to others contemplating spilling blood on the streets" (Devic 2009a: 3) that violence or antisocial activity are no longer tolerated. The most pertinent legacy of these new crime-related discourses is how they are so profoundly divorced from the signifiers of monstrous violence and virtual victimhood that were triggered by an intentional predatory rape in a desolate public alcove. Rather, the current focus is on more mundane elements of rowdiness in and immediately around the region's popular and heavily monitored "high-risk" venues where ID scanners are currently in use. Much of this disjuncture rests with acceptance of ID scanners as a viable, effective and unproblematic form of surveillance by the city's daily press.

\section{Conclusion}

Although producing the opposite result, this reporting sequence paradoxically resembles the media campaign against open space CCTV documented by Hier et al (2007). While numerous behind-the-scenes alliances invariably formalised the introduction of mandatory ID scanning in Geelong, the media's depiction of Luke Gill's "monstrous" violence came to signify any nightclub patron risked similar criminal victimisation. The ensuing media depiction of these issues overtly and tacitly neutralised any concerns over ID scanning either "from above" or "from below" due to the overriding pressure to combat the problem of alcohol-related violence through a radical overhaul of existing governance arrangements in the night-time economy. In this process, several new signals reinforced the success of this novel surveillance surge in protecting "us" from a different series of threats associated with the antisocial behaviour of drunken "thugs", "hoons", "yobbos" and "underage drinkers", who are now subject to tighter state regulatory scrutiny "from above". Meanwhile, the new banning regime only seems enforceable through a mass surveillance surge that impacts on all who participate in Geelong's night-time economy.

The discursive progression from immediate "outrage", to "concern", to limited "reflection", to the demand for urgent policy "solutions" and the ultimate depiction of ID scanners as an unqualified "success", modifies several binary discursive frames identified by Barnard-Wills (2011). For instance, persistent reassurances that Geelong's otherwise ungovernable night-time economy is now safe were generally supported by anecdotal statements from "primary definers" or case examples showing how ID scanners helped to detect a suspect, rather than any statistical evidence documenting substantial reductions in crime or antisocial behaviour. There were no criticisms of ID scanners as "mass, rather than targeted, surveillance" (Barnard-Wills, 2011: 557), where all "individuals have no choice" (Barnard-Wills, 2011: 562). Such concerns seem to interfere with the overriding and socially responsible focus on eliminating the scourge of alcohol-related disorder from the Geelong CBD. The "( $t$ )ransparency of surveillance practices ... as a positive value" (Barnard-Wills, 2011: 562) is only canvassed in terms of the benefits of ID scanners in deterring crime and antisocial behaviour. The limited burden of delays in lengthy queues, as patron data is entered into the system is an added bonus. Any concerns regarding data security, privacy and the problems of relying on back-end data assemblages to drive the prevailing crime prevention and law enforcement approach in this city (Haggerty and Ericson, 2000) are ultimately trumped by these perceived benefits and thus remain unworthy of rigorous debate.

In the absence of a viable method to enforce legislative or judicial alcohol-related bans in other designated areas in Victoria or elsewhere, popular depictions of Geelong's "success" risk generating a self-fulfilling prophecy associated with this particular "surveillance surge" (Murakami Wood 2009: 181). This has implications regardless of whether ID scanners are deployed as an individual business initiative (Loukidelis 2009) or through a coordinated political strategy "from above", either with or without substantial influence "from below" (Law, Justice and Safety Committee 2010). The present example points to a function creep where the Geelong experience can be viewed as either an idiosyncratic political 
moment, or a benchmark surveillance response to the problem of alcohol-related violence that other jurisdictions would be wise to follow. As this research demonstrates, the media's stance is potentially crucial in determining which approach will ultimately prevail.

\section{Acknowledgement}

The authors thank Owen Ormerod for his assistance with this component of the research, Kristian Martin for his insightful comments on an earlier draft of this paper and two anonymous referees who provided valuable feedback on the first iteration of this manuscript. This project was funded by the Criminology Research Council (Grant 42/08-09).

\section{References}

Adam, R. 2008. New Police Powers. Ban Plan for Drunks. Geelong News, 6 August: 5.

Armitage, R., G. Smyth, and K. Pease. 1999. Burnley CCTV Evaluation. Crime Prevention Studies, 10: $225-249$.

Barnard-Wills, D. 2011. UK News Media Discourses of Surveillance. The Sociological Quarterly, 52(4): 548-567.

Bennett, S. 2006a. Help Them Catch These Monsters. Police Renew Calls for Rape Witnesses. Geelong Advertiser, 4 December: 3 .

Bennett, S. 2006b. Nixon Worry on CBD Attack. Geelong Advertiser, 22 December: 5.

Bloomfield, B. 2001. In the Right Place at the Right Time: Electronic Tagging and Problems of Social Order/Disorder. The Sociological Review, 49(2): 174-201.

Breen, D. 2006a. No One Monitoring Security Cameras. Geelong Advertiser, 2 December: 5.

Breen, D. 2007a. ID Scan Plan an "Invasion of Privacy". Geelong Advertiser, 19 January: 7.

Breen, D. 2007b. Geelong's Liquor Accord Forces Clubs to Install ID Checks. No scan, No Clubbing. Geelong Advertiser, 12 October: 3.

Breen, D. 2007c. Scanners Delayed a Month. Geelong Advertiser, 17 October: 4.

Breen, D. 2008. Others Follow City's Anti-Violence Efforts. Geelong Advertiser 26 June: 7.

Connelly, S. 2011. Constructing Legitimacy in the New Community Governance. Urban Studies, 48(5): 929-946.

Coventry, G. and D. Palmer. 2008. Toward Constituting a Critical Criminology for Rural Australia. In The Critical Criminology Companion, ed. T. Anthony and C. Cunneen, 303-214. Sydney, NSW: Hawkins Press.

Craven, J. 2009. 'Nightclub Shake-Up', Geelong Advertiser, 2 September: 1.

Craven, J. 2010. Gill Appeal Anger - "Rapist Should Get 50 Years". Geelong Advertiser, 23 March, 2010: 7.

Cross, J.T. 2005. Age Verification in the $21^{\text {st }}$ Century. Swiping Away your Privacy. The John Marshall Journal of Computer and Information Law, 23(2): 363-410.

Devic, A. 2008. Hotelier Against Schoolie Scanners. Geelong Advertiser, 20 May: 4.

Devic, A. 2009a. Thug Banned from Geelong City Night Spots for a Year - Publican Enemy No.1. Geelong Advertiser, 8 September: 3.

Devic, A. 2009b. Newcastle Moves Rejected - Nightlife No Go. Geelong Advertiser, 12 December: 28.

Dickens, C. 2009. Scanner Goes Mobile. Police Get New Weapon in Fight Against Violence. Geelong Advertiser, 15 October: 3. Dorman, C. 2008. Room 99 Assault Prompts Club to Install ID scanners. Geelong Advertiser, 18 December: 3.

Editorial. 2006. All Night Drinks Stir the Demons. Geelong Advertiser, 6 December: 17.

Editorial. 2009. Latest nightlife plan gets Govt tick. Geelong Advertiser, 27 June: 21.

Felson, M., R. Berends, B. Richardson, and A. Veno. 1997. Reducing Pub Hopping and Related Crime. In Policing for Prevention: Reducing Crime, Public Intoxication and Injury (Crime Prevention Studies vol. 7), ed. R. Homel, $115-132$. New York, NY: Criminal Justice Press.

Fussey, P. 2008. Beyond Liberty, Beyond Security: The Politics of Public Surveillance. British Politics, 3(1): 120-135.

Geelong Advertiser. 2006. Wanted. City Rape Suspect. Geelong Advertiser, 7 December: 24-25.

Girling, E., I. Loader and R. Sparks. 1998. A Telling Tale: A Case of Vigilantism and its Aftermath in an English Town. British Journal of Sociology 49(3): 474-490.

Gladman, S. 2007. Hotel Gives Scanner the Thumbs Up. Positive ID Trial. Geelong Advertiser, 29 May: 7.

Goold, B., I. Loader, and A. Thumala. 2010. Consuming Security? Tools for a Sociology of Security Consumption. Theoretical Criminology, 14(1): 3-30.

Hadfield, P. 2008. From Threat to Promise: Nightclub "Security", Governance and Consumer Elites. British Journal of Criminology, 48(4): 429-447.

Hadfield, P., S. Lister, and P. Traynor. 2009. “This Town's a Different Town Today”: Policing and Regulating the Night-Time Economy. Criminology and Criminal Justice, 9(4): 465-485.

Haggerty, K.D. and R. Ericson. 2000. The Surveillant Assemblage. British Journal of Sociology, 51(4): 605-622.

Hier, S.P., J. Greenberg, K. Walby and D. Lett. 2007. Media, Communication and the Establishment of Public Camera Surveillance Programmes in Canada. Media, Culture \& Society, 29(5): 727-751.

Innes, M. 2004a. Crime as a Signal, Crime as a Memory. Journal for Crime, Conflict and the Media, 1(2): 15-22.

Innes, M. 2004b. Signal Crimes and Signal Disorders: Notes on Deviance as Communicative Action. The British Journal of Sociology, 55(3): 335-355.

Innes, M. 2007. The Reassurance Function. Policing: A Journal of Policy and Practice, 1(2): 132-141. 
Karstedt, S. 2007. Creating Institutions: Linking the 'Local' and the 'Global' in the Travel of Crime Policies. Police Practice and Research, 8(2): 145-158.

Krevor, B., J.A. Capitman, L. Oblak, J.B. Cannon, and M. Ruwe. 2003. Preventing Illegal Tobacco and Alcohol Sales to Minors through Electronic Age-Verification Devices: A Field Effectiveness Study. Journal of Public Health Policy, 24(3/4): 251-268.

Kulinski, T. and B. Monk. 2008. The Use of ID Reader-Authenticators in Secure Access Control and Credentialling. In Proceedings of the 2008 IEEE International Conference on Technologies for Homeland Security, pp. 246-251, Quincy FL: The Printing House. Available at http://ieexplore.ieee.org/xpls/abs all.jsp?arnumber $=4534458$.

Law, Justice and Safety Committee. 2010. Inquiry into Alcohol-Related Violence. Final Report. No. 74. Brisbane, Qld: Legislative Assembly, Law, Justice and Safety Committee at http://www .parliament.qld.gov.au/view/committees/documents/lcarc/reports/Report\%2074.pdf.

Lea, J. and K. Stenson. 2007. Security, Sovereignty and Non-State Governance "From Below", Canadian Journal of Law and Society, 22(2): 9-27.

Lippert, R. 2007. Urban Revitalisation, Security and Knowledge Transfer: The Case of Broken Windows and Kiddie Bars. Canadian Journal of Law and Society, 22(2): 29-53.

Lippert, R. and B. Wilkinson. 2010. Capturing Crime, Criminals and the Public's Imagination: Assembling Crime Stoppers and CCTV Surveillance. Crime Media Culture, 6(2): 131-152.

Liquor Control Reform Act, Victoria, 1998.

Loukidelis, D. (Information and Privacy Commissioner). 2009. Cruz Ventures Ltd (doing business as Wild Coyote Club) Order P09-01. British Columbia Information and Privacy Commissioner Decision No. 16. At http://www.oipc.bc.ca/PIPAOrders/2009/OrderP09-01.pdf.

Manning, P.K. 2008. A View of Surveillance. In Technocrime: Technology, Crime and Social Control, ed. S. Leman-Langlois, 209-242. Cullompton, EX: Willan Publishing.

McCahill, M. and C. Norris. 2002. CCTV in Britain. Urbaneye Working Paper no. 3. Centre for Technology and Society, Technical University of Berlin. http://www.urbaneye.net/results/ue_wp3.pdf.

McLure, D. 2006. Mandatory Sentencing Makes Sense. Pay the Price. Geelong Advertiser, 16 December: 37.

McNamara, J. 2006a. Shoppers Fear CBD After Dark. Geelong Advertiser, 2 December: 4.

McNamara, J. 2006b. Addy Steps Up Hunt for Suspect. Geelong Advertiser, 7 December: 4.

McNamara, J. 2006c. City Embraces Poster Campaign. Geelong Advertiser, 8 December: 3.

McNamara, J. 2006d. I'll Man Cameras Says Belmont Mum. Geelong Advertiser, 8 December: 3.

McNamara, J. 2006e. Brutal Rape Ignites Community Spirit. City Parent Patrol. Geelong Advertiser, 9 December: 4.

McNamara, J. 2007. Violence Crackdown. Geelong Advertiser, 8 December: 3.

McNamara, J. and D. Breen. 2006. Victim Staggers for Help. Geelong Advertiser, 2 December: 5.

Monahan, T. 2010. Surveillance in the Time of Insecurity. New Brunswick NJ: Rutgers University Press.

Monahan, T. 2011. Surveillance as Cultural Practice. The Sociological Quarterly, 52(4): 495-508.

Moore, P. 2006. Don't Tell Us We Can't Be Safer ... Make it Happen. Geelong Advertiser, 19 December: 17.

Mulligan, C.M. 2008. Perfect Enforcement of Law: When to Limit and When to Use Technology. Richmond Journal of Law and Technology, 14(4): 1-49.

Murakami Wood, D. 2009. The "Surveillance Society": Questions of History, Place and Culture. European Journal of Criminology, 6(2): 179-194.

Neuman, W.R., M.R. Just and A.N. Crigler. 1992. Common Knowledge: News and the Construction of Political Meaning. Chicago, Il: University of Chicago Press.

Newton, A. and A. Hirschfield. 2009. Measuring Violence In and Around Licensed Premises: The Need for a Better Evidence Base. Crime Prevention and Community Safety, 11(3): 171-188.

Norris, C. and G. Armstrong. 1999. Maximum Surveillance Society: The Rise of CCTV. Oxford, UK: Berg Publishers.

Oates, A. 2008. Ban List Plan to Stop Trouble. Geelong News, 26 November: 3.

Oliver, M.B. 1999. Caucasian Viewers' memory of Black and White Criminal Suspects in the News. Journal of Communication, 49(3): 46-60.

Osmond, C. 2010. Anti-social Behaviour and its Surveillant Inter-assemblage. Surveillance and Society, 7(3/4): 325-343.

Palmer, D., I. Warren, and P. Miller. 2011. ID Scanners in the Australian Night-Time Economy. IEEE Technology and Society Magazine, 30(3): 18-24.

Paton, Y. 2008. Security Upgrade. The Echo, 1 May: C01.

Peelo, M. 2006. Framing Homicide Narratives in Newspapers: Mediated Witness and the Construction of Virtual Victimhood. Crime Media Culture, 2(2): 159-175.

Pike, L. and D. Breen. 2006. Brutal Pack Bashing. Lara Man, 21, Undergoes Brain Surgery. Geelong Advertiser, 19 December: 4. Prytz, T. 2006. Attack Felt By Everyone ("Hot Topic"). Geelong Advertiser, 16 December: 14-15.

R.v. Gill [2010] VSCA 67.

Rumbold, G., A. Malpass, E. Lang, S. Cvetkovski and W. Kelly. 1998. Evaluation of the Geelong Local Industry Accord. Final Report. Melbourne Vic: Turning Point Alcohol and Drug Centre Inc.

Sentencing Advisory Council. 2007. Homicide in Victoria: Offenders, Victims and Sentencing. Melbourne Vic: Sentencing Advisory Council.

Squires, P. 2008. The Politics of Anti-Social Behaviour. British Politics, 3(3): 300-323. 
Smith, B. 2006. City Attacks Continue. Geelong Advertiser, 27 December: 3.

Smith, B. 2007. Police Claim Victory Over Violent Nightclub Attack. Scanner Saves Face. Geelong Advertiser, 4 June: 3.

Stenson, K. 2008. Governing the Local: Sovereignty, Social Governance and Community Safety. Social Work \& Society, 6(1) at http://www.socwork.net/2008/1/special issue/stenson.

Thompson, S. and G. Genosko. 2009. Punched Drunk: Alcohol, Surveillance and the LCBO. Black Point, Nova Scotia: Fernwood Publishing.

Tickell, D. 2009. Surf Coast Pubs to Scan IDs. Geelong Advertiser, 2 August: 9.

Tucker, R. 2006a. At Least One Alleged Attacker Caught on Tape: Police Suspect on Film. Geelong Advertiser, 5 December: 5.

Tucker, R. 2006b. First Pictures of City Rape Suspect. We'll Get You. Geelong Advertiser, 6 December: 1.

Tucker, R. 2006c. Rape Victim's Parent Writes of Pain and Hope. A Mother's Anguish. EXCLUSIVE. Geelong Advertiser, 11 December: 3.

Tucker, R. 2006d. Ten Helps in the Hunt. Geelong Advertiser, 15 December: 7.

Tucker, R. 2006e. Mother's Painful Journey. BRUTAL CITY RAPE. Geelong Advertiser, 23 December: 4-5.

Tucker, R. 2006f. Seven Officers in Hunt for Rapist. Geelong Advertiser, 21 December: 4.

Tucker, R. 2006g. Man Arrested. Geelong Advertiser, 25 December: 2.

Tucker, R. 2006h. A Phone Call That Helped Ease the Pain. Geelong Advertiser, 25 December: 2.

Tucker, R. 2007. Gifts to Show Victim We Care. Geelong Advertiser, 1 January: 5.

Tucker, R. 2009a. Leading by Example. Plan to Help Make City Safer. Geelong Advertiser, 3 June: 9.

Tucker, R. 2009b. More than 50 Convicted for Disgraceful Behaviour. City Centre Shame. Geelong Advertiser, 5 June: 7.

Unknown author. 2006a. BRUTAL CITY RAPE: ANIMALS. Geelong Advertiser, 2 December: 1.

Unknown author. 2006b. RAPE HORROR. Help Catch the Cowards. Geelong Advertiser, 4 December: 1.

Unknown author. 2006c. Corio Man, 28, Charged over Savage City Attack. BRUTAL RAPE ARREST. Geelong Advertiser, 25 December: 1 .

Waiton, S. 2010. The Politics of Surveillance: Big Brother on Prozac. Surveillance and Society, 8(1): 61-84.

Warren, I. 2009. Vigilantism, The Press and Signal Crimes 2006-2007. In ANZ Critical Criminology Conference Proceedings 2009, ed. M. Segrave, 275-284. Melbourne, Vic: Monash University at http://arts.monash.edu.au/criminology/c3conference-proceedings/anz-critical-criminology-conference-2009-proceedings.pdf.

Welch, M., M. Fenwick and M. Roberts. 1997. Primary Definitions of Crime and Moral Panic: A Content Analysis of Experts' Quotes in Feature Newspaper Articles on Crime. Journal of Research in Crime and Delinquency, 34(4): 474-494.

Welsh, B.C. and D. Farrington. 2009. Public Area CCTV and Crime Prevention: An Updated Systematic Review and MetaAnalysis. Justice Quarterly, 26(4): 716-745.

Whalley, J. 2006. Rape Victim Still Bears the Scars of 2001 Attack. Geelong Advertiser, 6 December: 4.

Whalley, J. 2008a. Computer System Could Hold Key to Geelong's Violence Problem. Geelong Advertiser, 5 May: 5.

Whalley, J. 2008b. Politicians Support CBD Trial Lockout. Geelong Advertiser, 14 May: 4.

Wilson, D. and A. Sutton. 2004. Watched Over or Watched? Open Street CCTV in Australia. The Australian and New Zealand Journal of Criminology, 37(2): 211-230. 